\title{
The Impact of the Iraq War on the Country Beta of MENA Markets
}

\author{
Hisham M. Al Refai \\ School of Economics and Finance, University of Western Sydney \\ Locked Bag 1797, Penrith South DC, NSW 1797, Australia \\ Tel: 61-2-9685-9261Ｅ-mail: h.alrefai@uws.edu.au
}

Received: September 2, 2010

Accepted: September 25, 2010

doi:10.5539/ijef.v3n2p12

\begin{abstract}
This paper utilizes the Kalman filter approach to examine the impact of the Iraq war on the country betas of 11 equity markets in the MENA region. The Kalman filter model allows the country beta to vary over time conditional on the interaction with Iraq war dummy in the transition equation. The results show that the Iraq war has a positive impact on the country betas of all the MENA countries under study but statistically significant for Egypt, Morocco, Tunisia, and Kuwait. The Iraq war has created a sudden shift in the time paths of the country betas, which reflected in a significant structural break and a dramatic increase of these equity market risks in the region. Although the impact of this geopolitical event is found to be limited to four markets in the region, the results correspond to the impact of the geopolitical events like the Iraq war on equity markets.
\end{abstract}

Keywords: Country beta, Iraq war, Kalman filter, MENA markets

\section{Introduction}

Most of financial decision-making in international setting needs to apply a framework of estimating the country risk level. The concern that systematic risk at the international level tends to be unstable and, hence, needs to be tested and modeled (Gangemi et al., 2000). The time varying country beta has become a persistent issue in the international finance especially the world markets have reached to rapid business environment, and this assessment of the country risk has become an important need for international investors (Brooks, 2003; Brooks et al., 2002). Although the assessment of the country risk in terms of the single factor model has found some objections in the literature especially for emerging markets, there is substantial evidence which suggests that in an international context, time variation in country risk is very meaningful for foreign investors (see for example, Brooks et al., 2002). Johansson (2009) argue that it is difficult to model the emerging markets' country betas as stable processes even if they are not fully integrated to the world markets (Note 1). He advocates a conditional approach to country beta estimation when looking at investment possibilities in developing countries.

\section{Global events and equity markets}

It is well-documented that international capital markets react, in terms of returns and volatility, quickly and simultaneously to major events. However, the timing and magnitude of changes in stock returns and volatility differ across markets around the world if their impact is limited only to integrated markets (Nikkinen et al., 2008). The subject that has become particularly relevant in light of recent worldwide events is the long-term effect of political instability on the fluctuations of stock markets (Fernandez, 2008). The empirical finance literature has paid increasing attention to the impact of the geopolitical events on stock market behavior. In particular, major political events such as war and terrorist attacks are reflected in asset prices (Amihud and Wohl, 2004; Chen and Siems, 2004; Athanassiou et al., 2006). Chen and Siems (2004) argue that events such as terrorist attacks, military invasions and other unforeseen disastrous occurrences can have serious implications for stocks and bonds.

It is possible that external or exogenous shocks like war or political tensions and other turbulent financial shocks can directly affect equity market returns and risk by increasing the volatility and have a direct implication for investment decisions or portfolio allocation (Amihud and Wohl, 2004; Rigobon and Sack, 2005). Malliaris and Urrutia (1995) analyze the international responds of the equity prices to the Persian Gulf crisis of 1991. They find that the national stock markets seem to have responded to the crisis period according to the countries dependent on oil imports. Using the GARCH family models, Athanassiou et al., (2006) examine the impact of geopolitical tension between Greece and Turkey on domestic stock market volatility, mainly, the impact of fluctuations in Greek-Turkish bilateral relations on the Athens Stock Exchange. They use the military tension index as a dummy crisis that reflects the ups and downs in the two countries' relations that led them to full military mobilization. Their empirical findings indicate that the escalation that could have led to armed conflict adversely affected stock market behavior. 
The Iraq war is considered as a major event that shook the global financial markets and disrupted the economies in the region. The war has also undermined the regional stock markets, and has caused political, regional, economical, and financial risks in the world and regional Middle Eastern economies (Rigobon and Sack, 2005; Nell and Semmler, 2007; Richardson, 2003; Leigh et al., 2009). Salameh (2008) argues that the Iraq war has impacted on the global oil production capacity by creating instability in the Middle East and thus increasing the risk of investing in the region. Shachmurove (2003) states that the countries surrounding Iraq are faced with greater uncertainty and the impact of the war is of an immediate concern. He states that the ongoing outcomes of the war has undermined regional stock markets and caused further political, regional, economical, and financial risks, and affected many significant components of the regional and international economic activities. Leippold and Lohre (2010) test for the dispersion effect in many companies in a sample of 16 emerging equity markets, 15 European markets, and the U.S. equity market, covering the period from 1987 to 2007 . They find one of the breakpoint coincides with the dawn of the Iraq war in March 2003.

The impact of the war and the regional instability of the Middle Eastern region have caused serious outcomes on the world economies. Leigh et al. (2009) argue that the negative effects of the Iraq war are larger for the regional countries that depend heavily on oil imports. Fernandez (2008) studies the volatility of worldwide stock markets primarily caused by the invasion of Iraq and the ongoing Israeli-Palestinian conflict. Her findings show that the greatest impact of such political instability was around the beginning of the Iraq war, and that the major international stock markets were those which became relatively more volatile around that time. Rigobon and Sack (2005) find that in ten weeks before the start of the war on Iraq, the risk of war explains between 13 and 63 percent of the variance of financial variables such as the S\&P 500 index, oil prices, gold prices and the US dollar. Leigh et $a l$. (2009) find that the U.S. stock market was extremely sensitive to changes in the probability of war; a $10 \%$ rise on the probability of war was accompanied by a $1.5 \%$ decline in the S\&P 500. Nell and Simmler (2007) claim that the Iraq war was a major cause of uncertainty throughout the world and has seriously damaged many weak economies that can not afford an increase in their oil imports.

The majority of these studies conclude that the financial markets around the world have reacted to major turbulent events in the last two decades. In addition, many regional and global events have been investigated in the literature. The paper contributes to the literature in different ways; first, the literature has not examined the impact of any of these global shocks on the country beta. Second, the impact of the Iraq war especially on the country beta of the regional markets has not been examined yet. This paper intends to fill the gap in the literature.

The structure of the paper is organized as follows: section 3 explains the empirical framework, the Kalman filter model, and description of the data of MENA equity markets. Section 4 presents the empirical results, section 5 summaries and concludes the study.

\section{Empirical framework}

There are several dynamic approaches to modeling the time-varying beta of the CAPM of Sharpe (1964) and Lintner (1965) including the Kalman Filter approach. The dynamic technique of the Kalman filter uses the state-space models to deal with time varying coefficient. The time-varying market model can be expressed as:

$$
\begin{array}{ll}
R_{i t}=\alpha_{i}+\beta_{i t} R_{m t}+\varepsilon_{i t}, & \varepsilon_{i t} \sim N\left(0, \sigma^{2}\right) \\
\beta_{i t}=\phi \beta_{i t-1}+\omega_{i t}, & \omega_{i t} \sim N\left(0, \sigma_{\omega}^{2}\right)
\end{array}
$$

Where $R_{i t}$ market returns on country $i$ in excess of the 3-months US. Treasury bill rate as a proxy for the international risk-free. $R_{m t}$ is the excess returns on the world returns. The state-space form of the time-varying market model above can be rewritten as:

$$
Y_{t}=\mathrm{Z}_{t} \mathrm{~B}_{t}+v_{t} \quad v_{t} \sim \mathrm{N}(0, \sigma)
$$

The state equation takes the form:

$$
\mathrm{B}_{t}=\phi \mathrm{B}_{t-1}+\omega_{t} \quad \omega_{t} \sim \mathrm{N}(0, \Xi)
$$

Where $Y_{t}$ is the country's market returns, and $\mathrm{B}_{t}$ is the unobserved state vector, and $Z_{t}=\left(1, R_{m t}\right)^{\prime}$ is a vector. The matrices $\phi, \sigma$ and $\Xi$ are assumed to be known, and the error terms $v_{t}$ and $\omega_{t}$ are serially independent from each other. By setting the transition matrix $\phi$ to the identity matrix, the model evolves as a random walk model. 


\subsection{The impact of the Iraq war}

The international CAPM is chosen as a benchmark model for evaluating the specifications of country beta with the dummy structural break of the Iraq war. The conditional model allows the country beta to vary over time conditional on the interaction with Iraq war dummy. The time that defines the war dummy must be carefully approximated to model the changes in country beta. The technique estimates the time varying country beta and the war dummy takes the following form:

$$
\begin{array}{ll}
R_{i t}=\alpha_{i}+\beta_{i t} R_{m t}+\varepsilon_{i t}, & \varepsilon_{t} \sim N\left(0, \sigma_{\varepsilon}^{2}\right) \\
\beta_{t}=\phi \beta_{i t-1}+\delta_{2} D_{\text {Iraq } 03}+\omega_{i t}, & \omega_{t} \sim N\left(0, \sigma_{\omega}^{2}\right)
\end{array}
$$

Where $\delta_{2}$ is the dummy variable which takes the value of 1 for the weeks of March to April, 2003 (Note 2), 0 otherwise. If $\delta_{2}=0$, then we conclude that the Iraq war did not affect the country beta of the MENA markets. The transition equation in the Kalman filter allows an explicit incorporation and direct interaction of the war dummy with evolution of the country betas over time. A significant positive (negative) coefficient of the war dummy reflects an increase (decrease) in the country beta after the war event. The analytical method is estimated by maximizing the log-likelihood function using the Berndt, Hall, Hall, and Hausman (1974) iterative algorithm. The paper also examines the redundancy of the dummy variable in the transition equation using the Wald restriction test.

\subsection{Data}

The financial data are weekly observations of the MENA equity markets indices. The collected data for 11 countries are based on the availability and length. Two main data groups are considered, first is the data available from the MSCI for the period of 1/03/1995 until 12/30/2008 for the markets of Egypt, Israel, Jordan, Morocco, and Turkey, a total of number of 731 observations, and the Qatar equity market for the period of 6/03/2002 to $12 / 30 / 2008$, a total number of 344 observations The second set for other MENA markets is available from S\&P for the markets of Lebanon, Oman, Saudi Arabia, and Tunisia for the period of 4/24/2000 to 12/30/2008; a total of number of 454 observations. The Kuwait equity market is sourced form the Kuwait Investment Company (KIW) for the period of 4/24/2000 to 12/30/2008; a total of number of 454 observations. All the data are sourced from Thomson DataStream, an existing database. The world MSCI is used as a proxy for the world index portfolio. The 3-month US Treasury bill rate is used as a proxy for the international risk free. All the returns are measured in US dollar denomination. The return series are converted to logarithmic returns as follows:

$$
R_{t}=100 \times \log \left(P_{t} / P_{t-1}\right)
$$

Where $P_{t}$ and $P_{t-1}$ are the prices for the equity markets in the sample and the world portfolio at time $t$ and $t-1$ respectively. $R_{t}$ represents the compounded rate of returns for an index $i$ at time $t$.

\section{Empirical results}

Table (1) reports the results of the Kalman filter model. The paper will focus on the outcomes of the dummy variable of the Iraq war only. The explanation of the dummy variable will be based on the following reasons, first, since the Iraq war has brought higher oil prices, we expect that the Iraq war will have a significant and positive impact on the country risk of the oil-importing countries and a negative impact on the country risk of the oil-exporting countries since these countries have experienced strong economic performance fueled by higher oil prices since the start of the Iraq war. The findings show that the Iraq war has a positive impact on the country betas of all the MENA countries but only Egypt, Tunisia, and Morocco as oil-importing countries have displayed significant reactions. Only Kuwait as oil-exporting country has displayed a significant and positive reaction to the event. The rest of the MENA markets are not significantly affected by the war event although the MENA countries are oil-importing and oil-exporting countries (see Page, 1999). The explanation would suggest that the combination of higher oil prices after the war, weaker consumer and local and international investor's confidence may have contributed largely to the increase in the country beta for Egypt, Tunisia, and Morocco. Besides, certain sectors in these countries have also suffered after the war particularly the tourism and the civil aviation.

The second reason is the political and regional uncertainty that undermined the investment and business environment in the region. The outcome of the war depends on whether the war achieves its objective of establishing a regime change in Iraq and political stability in the region. The longer the objective takes, the more it takes for trading and business activities to go back to normal. As Schneider and Troeger (2006) argue, investors trading on nearby markets to a conflict region will have the tendency to react positively to the increased confrontation and may flee the markets in mass. The Kuwait stock market activities have been suspended following 
the start of the invasion. Prior to the war, the uncertainty was when the war was going to start and when the war is going to end. This kind of regional uncertainty may have discouraged local and international investors to undertake their planned expenditure, asset allocation, and trading activities in the regional markets especially for the neighboring Kuwait, which has reflected in a significant increase in the country beta.

The significant and positive dummy suggest a sudden shift in country risk, which reflected in a major structural break and a dramatic increase of the country beta of these countries. The magnitude of the coefficient of the dummy variable is extremely high for to Egypt and Morocco followed by Tunisia and Kuwait.

In summary, these results correspond to the strength of the geopolitical impact on the country beta of these equity markets. Starting in March, 2003 with an anticipation of quick victory and short scenario of toppling the Iraqi regime and establishing democracy and stability in Iraq, the prolonged scenario and the aftermath of the war not only destabilized the equity markets in the region and their economies due to the skyrocketed oil price records, but also have led to negative anticipations for both local and international investors in the regional markets, which have aggravated the country beta of these markets in the MENA region. Also, it's logical to assume that the Iraq war have disrupted the regional trading activities and affected the profits of the firms in the region.

\section{Insert table (1) about here}

The Wald test hypothesis fails to reject the null hypothesis that the war dummy variable is equal to zero for Egypt, Tunisia, Morocco, and Kuwait. Figure (1) shows the time paths of the conditional country betas estimated by the Kalman filter for Egypt, Tunisia, Morocco, and Kuwait. The figure clearly shows the common upward trend and major structural break in country beta post the Iraq war. The country betas have experienced a strong surge in aftermath of the Iraq war compared to other MENA equity markets in the region.

\section{Insert figure (1) about here}

\section{Conclusion}

This paper evaluates the impact of the Iraq war on the country betas of 11 equity markets in the MENA region using weekly data. The results sustain the evidence on the impact of the geopolitical events like the Iraq war in the MENA region. Moreover, the magnitude of the war is stronger on the market beta of Egypt and Morocco. It's logical to conclude that as country beta increases, investors may suffer substantial losses and lowered returns when unexpected shift in beta occurs, and this means that as the market beta experience structural break, local and international investors might demand higher average returns to compensate for reinvesting in such risky markets. Also, the substantial and highly changes in country betas have important implications for policy markers in the MENA region. The more the market beta show more signs of very sudden and volatile changes during turbulent periods in the region, the more local and international investors might exercise more caution when reinvesting in these markets.

\section{References}

Amihud, Y. \& Wohl, A. (2004). Political News and Stock Prices: The Case of the Saddam Hussein Contracts. Journal of Banking and Finance, 28, 1185-2000.

Arouri, M. (2004). The Impact of Increasing Stock Market Integration on Expected Gains from International Portfolio Diversification: Evidence from a Multivariate Approach with Time Varying Risk. Economic Bulletins, 6, $1-13$.

Arouri, M. (2006). International Asset Pricing and World Market Integration: Evidence from a Partially Integrated ICAPM with Asymmetric Effects. Frontiers in Finance and Economics, 3, 70-94.

Athanassiou, E., Kollias, C. \& Syriopoulos, T. (2006). Dynamic Volatility and External Security Related Shocks: The Case of the Athens Stock Exchange. Journal of International Financial Markets, Institutions and Money, 16, 411-24.

Bekaert, G. \& Harvey, C. (1995). Time-Varying World Market Integration. Journal of Finance, 1, 403-44.

Berndt, E., Hall, B., Hall, R. \& Hausman, J. (1974). Estimation and Inference in Nonlinear Structural Models. Annals of Economic and Social Measurement, 3, 653-65.

Brooks, C., Faff, R. \& McKenzie, M. (2002). Time-Varying Country Risk: An Assessment of Alternative Modelling Techniques. The European Journal of Finance, 8, 249-74.

Brooks, R. (2003). Time Varying Betas on China's A and B Share Indices. In: Proceedings of the 15th Annual Conference of the Association for Chinese Economics Studies Australia (ACESA), Melbourne.

Bruner, R., Li, W., Kritzman, M., Myrgren, S. \& Page, S. (2008). Market Integration in Developed and Emerging 
Markets: Evidence from the CAPM. Emerging Markets Review, 9, 89-103.

Chen, A. \& Siems, T. (2004). The effects of Terrorism on Global Capital Markets. European Journal of Political Economy, 20, 249-66.

Fernandez, V. (2008). The War on Terror and its Impact on the Long-Term Volatility of Financial Markets. International Review of Financial Analysis, 17, 1-26.

Gangemi, M., Brooks, R. \& Faff, R. (2000). Modelling Australia's Country Risk: A County Beta Approach. Journal of Economics and Business, 52, 259-76.

Johansson, A. (2009). Stochastic Volatility and Time-Varying Country Risk in Emerging Markets. The European Journal of Finance, 15, 337-63.

Leigh, A., Wolfers, J. \& Zitzewitz, E (2009). Using Markets to Inform Policy: The Case of the Iraq War. Economica, 76, 225-250.

Leippold, M. \& Lohre, H. (2010). The Dispersion Effect in International Stock Returns. Available at: http://papers.ssrn.com/sol3/papers.cfm?abstract_id=1139412.

Lintner, J. (1965). The Valuation of Risk Assets and the Selection of Risky Investments in Stock Portfolios and Capital Budgets. Review of Economics and Statistics, 47, 13-37.

Malliaris \& Urrutia (1995). The Impact of the Persian Gulf Crisis on National Equity Markets. Advances in International Banking and Finance, 1, 43-65.

Nell, E. \& Semmler, W. (2007). The Iraq War and the World Oil Economy. Constellations, 14, 557-85.

Nikkinen, J., Omran, M., P., Sahlstrom, P. \& Aijo, J. (2008) Stock returns and Volatility Following the September 11 Attacks: Evidence from 53 Equity Markets. International Review of Financial Analysis, 17, 27-46.

Page, J. (1999). The Impact of Lower Oil Prices on the Economies of Gulf States. Middle East Policy, 6, 59-67.

Richardson, D. (2003). Economics of War with Iraq. Economics, Commerce and Industrial Relations Group. Current Issues Brief No. 20, 2002-03.

Rigobon, R. \& Sack, B. (2005). The Effects of War Risks on the U.S Financial Markets. Journal of Banking and Finance, 29, 1769-89.

Salameh, M. (2008). The Oil "Price Rise" Factor in the Iraq War: A Macroeconomic Assessment. The United States Association for Energy Economics (USAEE), Working paper No. 08-008.

Schneider, G. \& Troeger, V. (2006). War and the World Economy: Stock Market Reactions to International Conflicts. Journal of Conflict Resolution, 50, 623-48.

Shachmurove, Y. (2003). Financial Markets of the Middle East and North Africa: The Past and Present. Penn Institute for Economic Research, University of Pennsylvania, Working Paper No. 03-017.

Sharpe, W. F. (1964). Capital Asset Prices: A Theory of Market Equilibrium under Conditions of Risk. Journal of Finance, 19, 425-42.

\section{Notes}

Note 1. Empirical studies investigating stock market integration to developed and emerging markets include the studies of Bekaert and Harvey (1995), Arouri (2006), Arouri et al. (2004), Gerard et al. (2007), among other. However, the failure to reject the market integration hypothesis must not be taken as strong evidence against some degree of market segmentation (Bruner et al., 2008).

Note 2. Although the war lasted longer than 2 months, it's when the former president of the United States, George W. Bush declared: mission accomplished on the aircraft carrier USS Abraham Lincoln on May 1, 2003. 
Table(1): The Dynamic Kalman filter approach with the Iraq war dummy

\begin{tabular}{|c|c|c|c|c|c|c|}
\hline & $\alpha_{i}$ & AIC & $\beta_{t}$ & Log-likelihood & $\delta_{2}$ & Wald test \\
\hline Egypt & $\begin{array}{l}0.190 \\
(1.335)\end{array}$ & 5.50 & $\begin{array}{l}\mathbf{1 . 1 2 8}^{\mathbf{a}} \\
(7.334)\end{array}$ & 2014.53 & $\begin{array}{l}\mathbf{0 . 1 3 0}^{\mathbf{a}} \\
(3.249)\end{array}$ & $10.552^{\mathrm{a}}$ \\
\hline Israel & $\begin{array}{l}0.069 \\
(0.643) \\
\end{array}$ & 4.973 & $\begin{array}{l}\mathbf{0 . 6 9 4}^{\mathbf{a}} \\
(4.015) \\
\end{array}$ & 1811.23 & $\begin{array}{l}0.062 \\
(1.513) \\
\end{array}$ & 2.290 \\
\hline Jordan & $\begin{array}{l}0.041 \\
(0.428)\end{array}$ & 4.714 & $\begin{array}{l}\mathbf{0 . 8 1 2}^{\mathbf{a}} \\
(7.272)\end{array}$ & 1716.76 & $\begin{array}{l}0.023 \\
(0.608)\end{array}$ & 0.370 \\
\hline Kuwait & $\begin{array}{l}\mathbf{0 . 1 4 7 ^ { c }} \\
(1.720)\end{array}$ & 4.392 & $\begin{array}{l}\mathbf{0 . 4 6 1}^{\mathbf{a}} \\
(3.629) \\
\end{array}$ & 1596.06 & $\begin{array}{l}\mathbf{0 . 0 6 4}^{\mathrm{c}} \\
(1.659)\end{array}$ & $2.753^{c}$ \\
\hline Lebanon & $\begin{array}{l}0.196 \\
(0.818)\end{array}$ & 5.940 & $\begin{array}{l}\mathbf{0 . 6 0 1}^{\mathbf{a}} \\
(3.520)\end{array}$ & 1341.41 & $\begin{array}{l}0.000 \\
(0.006)\end{array}$ & 0.001 \\
\hline Morocco & $\begin{array}{l}\mathbf{0 . 1 5 9}^{\mathbf{c}} \\
(1.715) \\
\end{array}$ & 4.687 & $\begin{array}{l}0.266 \\
(1.177) \\
\end{array}$ & 1706.66 & $\begin{array}{l}\mathbf{0 . 1 3 6}^{\mathbf{b}} \\
(2.167) \\
\end{array}$ & $4.696^{b}$ \\
\hline Oman & $\begin{array}{l}0.170 \\
(1.290)\end{array}$ & 4.833 & $\begin{array}{l}\mathbf{0 . 5 0 9}^{\mathbf{b}} \\
(2.307)\end{array}$ & 1088.62 & $\begin{array}{l}0.024 \\
(0.417)\end{array}$ & 0.173 \\
\hline Qatar & $\begin{array}{l}0.274 \\
(1.066)\end{array}$ & 5.967 & $\begin{array}{l}\mathbf{0 . 6 3 6}^{\mathbf{a}} \\
(6.560)\end{array}$ & 1018.25 & $\begin{array}{l}0.056 \\
(1.035) \\
\end{array}$ & 0.786 \\
\hline Saudi Arabia & $\begin{array}{l}0.179 \\
(0.875)\end{array}$ & 5.572 & $\begin{array}{l}\mathbf{0 . 6 0 6}^{\mathbf{a}} \\
(3.599)\end{array}$ & 1256.03 & $\begin{array}{l}0.006 \\
(0.079)\end{array}$ & 0.006 \\
\hline Tunisia & $\begin{array}{l}0.046 \\
(0.463)\end{array}$ & 4.225 & $\begin{array}{l}\mathbf{0 . 2 7 8}^{\mathbf{a}} \\
(3.085) \\
\end{array}$ & 951.80 & $\begin{array}{l}\mathbf{0 . 0 4 7}^{\mathrm{a}} \\
(2.936)\end{array}$ & $8.617^{\mathrm{a}}$ \\
\hline Turkey & $\begin{array}{l}0.097 \\
(0.383)\end{array}$ & 6.687 & $\begin{array}{l}\mathbf{1 . 4 7 1}^{\mathrm{a}} \\
(3.613)\end{array}$ & 2436.72 & $\begin{array}{l}0.194 \\
(1.619)\end{array}$ & 2.621 \\
\hline
\end{tabular}

Notes: a , b c are significant at $1 \%, 5 \%$, and $10 \%$ respectively. The model is estimated by the maximum likelihood methods described by Berndt, Hall, Hall, and Hausman (1974) iterative algorithm.
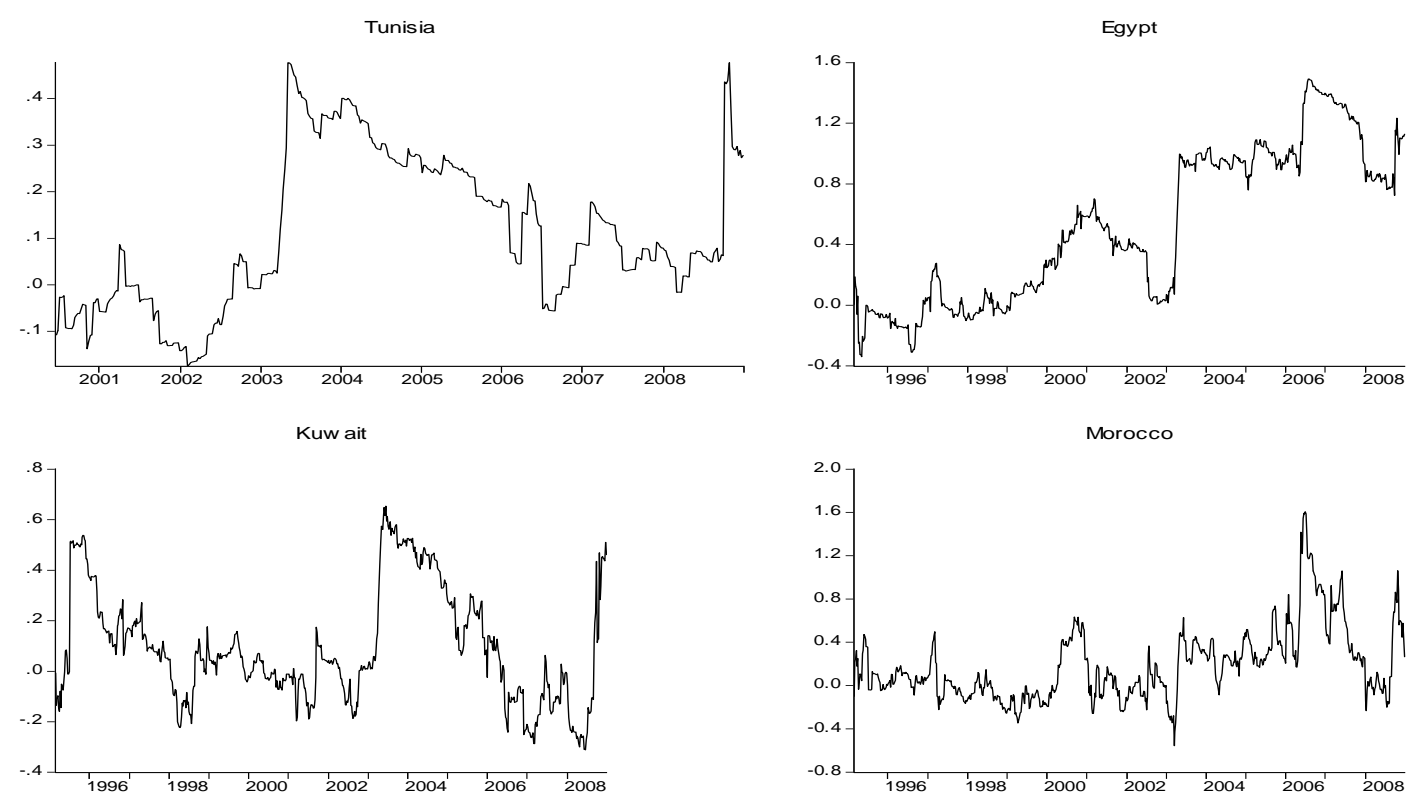

Figure (1). Time varying country beta with the structural break for the Iraq war. 